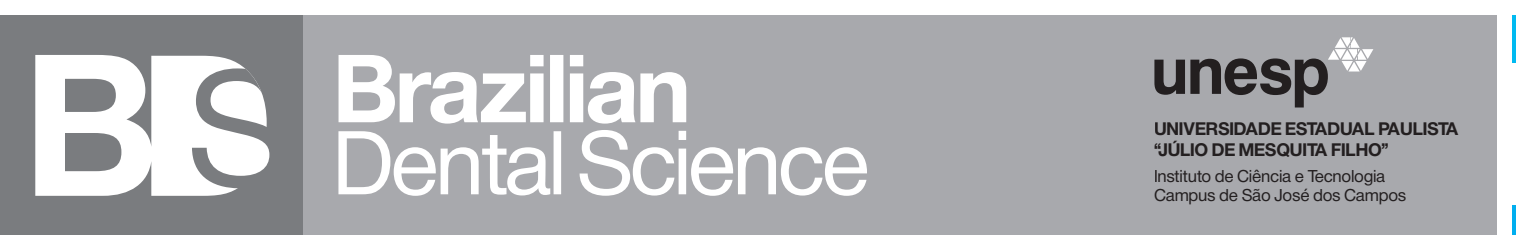

\title{
Development and Validation of Perceived Oral Health Benefits on Yoga Scale (POBYS)
}

\author{
Desenvolvimento e validação da Escala de Benefícios da Saúde Oral Percebidos no Yoga (POHBYS) \\ Acharya BALKRISHNA ${ }^{1}$, Kuldeep SINGH ${ }^{2}$, Abhishek SHARMA ${ }^{3}$, Nagarajan KARTHIKEYAN ${ }^{4}$, Paran GOWDA \\ 1 - University of Patanjali, Uttarakhand, India \\ 2 - Dental Clinic and Research Centre, Patanjali Ayurved Hospital, Haridwar, Uttarakhand, India \\ 3 - Public Health Dentistry, RUHS College of Dental Sciences (Government Dental College and Hospital), Jaipur, Rajasthan. \\ 4 - Patanjali Research Institute, Haridwar, Uttarakhand, India. \\ 5 - University of Patanjali, Haridwar, Uttarakhand, India.
}

\section{ABSTRACT}

Objective: Sustained practice of Yoga leads to selfawareness, physical strength and high sense of energy. Yoga stimulates antioxidant levels in the body and reduces likelihood of dental disorders. No research has been undertaken connecting perception on yoga and oral health behaviors. The present study is an attempt to develop a psychometric scale entitled Perceived Benefits on Yoga Scale (PBYS) to measure individuals' perception on Yoga in relation to oral health behaviors. Material and methods: The psychometric tool was developed based on the concepts of Health Benefit Model (HBM). Among the four components of the model, the present study considered "perceived benefits" component. A total of 206 individuals participated in the study. To analyze the scale theoretically, face and content validity were assessed. Reliability of the scale was tested using Cronbach's alpha and SpearmanBrown coefficient. Using exploratory and confirmatory factor analysis, construct validity was tested. Cronbach alpha and Spearman-Brown coefficient were applied to test the reliability of scale. Results: There were six items in the final scale, with a Spearman- Brown coefficient of 0.92 and Cronbach's alpha of 0.91. Statistically significant $(\mathrm{p}<0.001)$ positive correlation was found between POBYS scores and Yoga Self-Efficacy Scale (YSES). Validity of scale is within accepted range as indicated by Goodness of Fit indices. Conclusion: POBYS is a reliable and valid measure of perception on yoga outcomes with specific reference to oral health behavior.

\section{KEYWORDS}

Yoga; Health belief model; Oral health behavior; Scale development; Confirmatory factor analysis.

\section{RESUMO}

Objetivo: A prática continua de Yoga leva ao autoconhecimento, força física e a sensação de energia elevada. O yoga estimula os níveis de antioxidantes no corpo e reduz a probabilidade de desordens dentais. Nenhuma pesquisa foi realizada conectando a percepção sobre o yoga e os comportamentos da saúde bucal. O presente estudo é uma tentativa de desenvolver uma escala psicométrica intitulada Escala de Benefícios Percebidos no Yoga (PBYS) para medir a percepção dos indivíduos sobre o Yoga em relação aos comportamentos da saúde bucal. Material e Métodos: A ferramenta psicométrica foi desenvolvida com base nos conceitos do Modelo de Benefícios à Saúde (HBM). Dentre os quatro componentes do modelo, o presente estudo considerou o componente "benefícios percebidos". Participaram do estudo 206 indivíduos. Para analisar teoricamente a escala, foram avaliadas a validade de face e de conteúdo. A confiabilidade da escala foi testada usando o alfa de Cronbach e o coeficiente de Spearman-Brown. Usando análise fatorial exploratória e confirmatória, a validade do construto foi testada. O alfa de Cronbach e o coeficiente de SpearmanBrown foram aplicados para testar a confiabilidade da escala. Resultados: Havia seis itens na escala final, com coeficiente de Spearman-Brown de 0,92 e alfa de Cronbach de 0,91. Estatisticamente significativo ( $\mathrm{p}<0,001$ ) foi encontrada correlação positiva entre os escores do PBYS e a Escala de Autoeficácia do Yoga (YSES). A validade da escala está dentro da faixa de aceitabilidade conforme indicado pelos índices de Goodness of Fit. Conclusão: PBYS é uma medida confiável e válida de percepção sobre os resultados do yoga com referência específica ao comportamento de saúde bucal.

\section{PALAVRAS-CHAVE}

Yoga; Modelo de crença saudável; Comportamento de saúde bucal; Desenvolvimento de escala; Análise fatorial confirmatória. 


\section{INTRODUCTION}

$\mathrm{P}$ sychological stress and oral diseases are related. Oral pain related diseases and disorders like burning mouth syndrome, recurrent aphthous stomatis, glossodynia, bruxism etc. have been observed to occur among people with emotional stress [1]. It has been hypothesized that physical or emotional stress stimulates several endocrine and immune pathways. It has been proved that immunemodulators and inflammatory cytokines are released during the process and this leads to inflammation. Oxidative stress in the body induces release of reactive oxygen species resulting in different diseases, including dental caries, gingivitis, and periodontitis, etc. [2].

Yoga, one of the ancient concepts of India is increasingly being signified in the modern science as a holistic approach to health. Yoga Sutras written by Patanjali is recognized as the authoritative manuscript of Yoga, in which philosophies and practices of Yoga are described [3]. The National Institute of Health (U.S. Department of Health and Human Services) has classified Yoga as a form of Complementary and Alternative Medicine. It has been proved that sustained practice of Yoga promotes physical strength and flexibility and enables traits such as kindness, sociability, calmness and self-discipline. The regular practice of Yoga also results in outcomes like enhanced selfawareness, changes in life perspective and high sense of energy. The Yoga practice promotes a sense of equilibrium and union between mind and body [4]

The eight limbs of Yoga, as narrated by Patanjali, are comprised of values, principles and practices, which serve as a recommendation to live a healthy and meaningful life with morality, ethics and self-discipline. Practice of Yoga stimulates the antioxidant levels in the body. Studies showed that Yoga practice enhances release of antioxidants and reduces oxidative stress in case of disorders namely renal disease and diabetes [5]. Yoga reduces the inflammatory response, improves immunity and reduces the likelihood of prevalence dental disorders.

Oral hygiene plays a vital role in preventing oral diseases. Educating the patients on oral hygiene is one of the key responsibilities of the dental hygiene professionals. The primary objective of patient education is to offer patients information that helps them make informed lifestyle choices. The early patient educational strategies envisaged direct communication between the healthcare provider and the patient, which insisted the patients to comply with prescribed self-care routines. Less attention was paid to the individual's perception of health and disease. After 1950's, theories associated with perception and belief of individuals in making health decisions were developed. Health Benefit Model (HBM) is one of the pioneering theories widely adopted in oral health sciences [6]. Even though Yoga has been proved to have positive health outcomes, research on measuring health behaviors in the light of Yoga is meagre. Bandura [7] has developed an Exercise Self-Efficacy Scale. Sohl et al. [8] and Birdee et al. [9] have developed scales for measuring beliefs on Yoga. However, no research has been undertaken connecting perception on yoga and oral health behaviors. The present study is an attempt to develop a psychometric scale to measure individuals' perception on Yoga in relation to oral health behaviors applying the concepts of HBM.

HBM, one of the initial attempts to link health with social and psychological elements, was first proposed by Hockbaum. The core principle of HBM is that people who have better information will make better health decisions. Perceived threats and benefits found base for the HBM. The model is comprised of four components namely perceived susceptibility, perceived severity, perceived benefits and perceived barriers. He proposed that these four components are attributed to the people's 
readiness to act [10]. Of these four components, the present study considered only perceived benefits component to develop scale as the Yoga concept has been constructed on the element of positivism. Patanjali, in Yoga Sutras, highlights that Shraddha is crucial in determining the effect of Yoga practice on physical and mental health of an individual. Shraddha is a Sanskrit word having an equivalent meaning of faith [11]. Since the Shraddha describes a positive type of energy that comes from deep within each individual that shapes his/her world and life, the positive component of HBM, perceived benefits only was considered in the study.

\section{MATERIAL AND METHODS}

\section{Ethical clearance}

Study was approved by Institutional Ethical Committee (IEC) vide Letter No. PAC/1002/20.03.2018 and participants signed informed consent letter.

\section{Sampling}

As per recommendation of Hoelter [12], Hinkin and DeVellis [13] and previous literature, a sample size of greater than 200 was decided to ensure the sample adequacy. The present study on scale validation was conducted with sample of 206 Indian individuals who were selected based on convenient sampling basis. The individuals who visited Ayurvedic Hospital, Dental Clinic and Research Centre of Patanjali Yogapeeth, were invited to participate in the study. Inclusion criteria for the study included individuals aged 18 years and above, both male and females who consented to participate.

Individuals who refused to consent, uncooperative behavior, were excluded from study.

\section{Procedures of scale development}

Development of POBYS scale involved three stages, which included item generation, theoretical analysis and psychometric analysis.

\section{Item generation}

Content domain was specified through review of literature related to behavioral theories specified in psychology. Among the different theories, Health Belief Model that relates beliefs with behavior was considered to specify the content domain. The model comprises of four concepts namely perceived susceptibility, perceived severity, perceived benefits and perceived barriers [14]. Here, we focused on perceived benefits like a construct for development of a scale. In the present study, various deductive and inductive methods were applied to generate initial pool of items. Authors reviewed literature related to the Health Benefit Model, to Yoga and to oral health behavior to acquire basic comprehension about the concept and to develop constructs and items. Interaction was done with specialists from yoga and dental health care. Information was sought from patients vising Dental care centre, regarding contents of domain and objective of research. Analysis was made with collected information about perceived benefits to initiate pool items and finally a twelve item scale was developed.

\section{Theoretical analysis}

Content validity of the initial items was assessed to make sure that the items are representative of the identified construct i.e. Perceived Benefits on Yoga. Using Content Validity Index (CVI), relevance of each scale item was assessed in regard with criteria adopted. Each item was rated on a four-point scale $(1=$ Not relevant, $2=$ Somewhat relevant, $3=$ Quite relevant and $4=$ Highly relevant). Items which got score of 1 or 2 were opted out and items with score 3 or 4 were retained in scale. Twenty volunteers checked visual appearance of scale including user friendliness, style and formatting of items. 


\section{Psychometric analysis}

Confirmatory and exploratory factor analysis were used to test validity. Cronbach Alpha, Spearman-Brown coefficient measured reliability of scale and correlation between developing scale and previous YSES determined concurrent validity.

\section{Data collection and analysis}

Likert scale, a quantitative technique meant for measuring psychological variables like attitude, perception, anxiety, stress, beliefs etc... was used. There are five choices in scale ranging from 1 (strongly disagree) to 5 (strongly agree). Score of all items was summated and used in quantitative analysis. Scale was developed in English and hindi (local language) for easy understanding of participants. All statistical analysis was done using IBM SPSS 25.0 Software. Average variance extraction method was applied to measure convergent validity, model fitness indices, outputs from factor analysis, assessed construct validity. Modification indices were used to test discriminant validity by assessing redundancy level of items.

\section{RESULTS}

\section{Item generation}

After defining the content domain, items that relate Yoga, perceived benefits and oral health were generated through review of literature and information collected through interaction with relevant people. Regular practice of Yoga promotes self-control and well-being, self-awareness and self-confidence and sense of balance and union between mind and body. There were also evidences that the concept of Yoga approaches the human body as a holistic entity and healing of any one dimension is related to entire other dimensions of the body [3]. Hence, while considering oral health in the light of Yoga, general health also should be taken into account. Yoga through improving general health promotes positive effects related to gum and dental diseases. As an outcome of this exercise, twelve items such as stress reduction, self-discipline related to oral health, reduction in bad breath, prevention of gum bleeding, enhanced gum health and dental health, self-discipline related to general health, enhanced general health, positive eating habits, reduced smoking and alcohol practices, increased tooth-brushing frequency and increased self-confidence about general and oral health were generated as the initial pool of items.

\section{Theoretical analysis}

Twelve-item initial scale was vetted (content validity) by experts, who had (more than 10 years of experience in the field of yoga and dental sciences They used CVI rating tool. Items with index Score less than 0.86 were excluded from initial list. Six items related to reduction in bad breath, prevention of gum bleeding, positive eating habits, reduced smoking habits; reduced alcohol consumption and increased tooth brushing frequency were rejected.

In nextstage, modified scalewas distributed among 20 individuals who practiced yoga daily. Every item of scale was told to participant and response was taken of what they understood. In case of mismatch of understanding of content between participant and researcher, issues underneath like ambiguity, leading statements, complicated words were explored. They were modified and rephrased again told to participants and feedback was taken. If there was similarity, item was marked as qualified. As a result, six items were developed. Table I. 
Table I - Perceived Oral Health Benefits on Yoga Scale - Final items in scale

\begin{tabular}{cc|}
\hline Construct & Items \\
\hline $\begin{array}{c}\text { Perceived } \\
\text { benefits of } \\
\text { Yoga on oral } \\
\text { health }\end{array}$ & $\begin{array}{c}\text { Yoga practice helps improve self-discipline related to general } \\
\text { health }\end{array}$ \\
\hline & $\begin{array}{c}\text { Yoga practice helps improve self-discipline related to oral health } \\
\text { Yoga practice promotes general health }\end{array}$ \\
\hline & Yoga practice keeps gums healthy \\
\hline & Yoga practice keeps teeth healthy \\
\hline
\end{tabular}

\section{Psychometric analysis}

\section{Exploratory factor analysis}

This six item scale was then distributed to 206 study participants. Sample was found adequate using Kaiser - Meyer- Olkin (KMO) value. (0.94). statistically significant result as found when Bartlett's Test of Sphericity value was applied to find association between variables. principal factor, explaining $89.36 \%$ of total variance was extracted using Principal Component Analysis. Factor load values of all items were found more than 0.5 so all items of scale were further subjected to confirmatory factor analysis.

\section{Confirmatory factor analysis}

Confirmatory factor analysis was done by using equation modelling to test factor structure having one latent factor and six observed variables. (Figure 1)

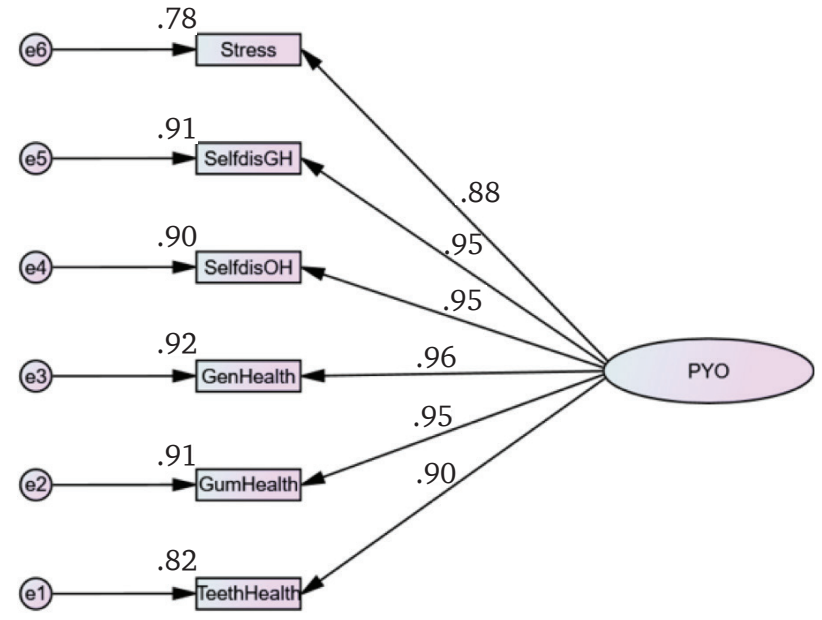

Figure 1 - PBYS model produced by confirmatory factor analysis.
The factor loadings for the six items obtained from the confirmatory analysis are given in Table II.

Table II - Factor loadings of the scale using factor analysis

\begin{tabular}{|ccc|}
\hline SI. No & Item & Factor load \\
\hline 1. & $\begin{array}{c}\text { Yoga practice helps reduce stress } \\
\text { 2. }\end{array}$ & $\begin{array}{c}\text { Yoga practice helps improve self-discipline related to } \\
\text { general health }\end{array}$ \\
\hline 3. & $\begin{array}{c}\text { Yoga practice helps improve self-discipline related to oral } \\
\text { health }\end{array}$ & 0.95 \\
\hline 4. & Yoga practice promotes general health & 0.95 \\
\hline 5. & Yoga practice keeps gums healthy & 0.96 \\
\hline 6. & Yoga practice keeps teeth healthy & 0.95 \\
\hline
\end{tabular}

Construct validity: Minimum of one model fitness index having categories, namely absolute fit, incremental fit and Parsimonious fit should be used in factor analysis for construct validity. Table III depicts results of model fitness indices.

Table III - Model fitness indices computed for the compared with acceptable levels

\begin{tabular}{|c|c|c|c|}
\hline $\begin{array}{l}\text { Name of } \\
\text { category }\end{array}$ & Index & $\begin{array}{l}\text { Accepted } \\
\text { level }\end{array}$ & $\begin{array}{l}\text { Study } \\
\text { result }\end{array}$ \\
\hline \multirow{3}{*}{ Absolute fit } & Discrepancy Chi Square (Chi-square) & $p>0.05$ & 0.136 \\
\hline & $\begin{array}{l}\text { Root Mean Square of Error Approxi- } \\
\text { mation (RMSEA) }\end{array}$ & $<0.08$ & 0.050 \\
\hline & Goodness of Fit Index (GFI) & $>0.90$ & 0.979 \\
\hline \multirow{4}{*}{$\begin{array}{l}\text { Incremental } \\
\text { fit }\end{array}$} & Adjusted Goodness of Fit (AGFI) & $>0.90$ & 0.950 \\
\hline & Comparative Fit Index (CFI) & $>0.90$ & 0.997 \\
\hline & Tucker-Lewis Index (TLI) & $>0.90$ & 0.996 \\
\hline & Normed Fit Index (NFI) & $>0.90$ & 0.998 \\
\hline $\begin{array}{l}\text { Parsimonious } \\
\text { fit }\end{array}$ & $\begin{array}{l}\text { Chi Square/Degrees of } \\
\text { Freedom (Chi-square/df) }\end{array}$ & $<3$ High & 1.51 \\
\hline
\end{tabular}

Convergent validity: Average Variance Expected (AVE) was quantified to test convergent validity. Statistical significance of all the items in the model indicates presence of convergent validity. The value of AVE was 0.873 for the scale under consideration.

Concurrent validity: A previous Yoga Self Efficacy Scale (YSES), developed in American context, consisting of three constructs and twelve items was used to examine concurrent validity 
of proposed scale. Cronbach alpha value of 0.89 was obtained when scale administered in present study, YSES has Cronbach's alpha value of 0.93, and good construct validity measures. Both scores were positively correlated when Spearman's correlation test was applied. (p-value $<0.001$ )

\section{Reliability}

Score for Cronbach's alpha was found 0.91 while Spearman-Brown coefficient of split half reliability and Composite reliability measure were measured as 0.92 and 0.87 respectively.

\section{Descriptive statistics}

The mean and median values of the PBYS scale were 17.60 and 19 respectively. The mean values had standard deviation of 7.80. The total scores of the scale ranged from 6 to 30. The scores were negatively skewed $(-0.158)$ with a standard error of 0.169 and the kurtosis value was -1.070 with a standard error of 0.337 . The total score values were not normally distributed. The Shapiro-Wilk statistic was .920 and it was significant ( $\mathrm{p}<0.001)$, which indicated that the data are not normally distributed.

\section{General characteristics of the sample}

Majority of the study participants were men $(58.74 \%)$. Mean age of the participants was $40.88 \pm 15.12$ years. Among the 206 total participants $72.33 \%$ practiced Yoga. Majority (51.46\%) of the respondents brushed teeth once a day followed by twice a day (44.18\%) and thrice a day $(2.91 \%)$. Slightly higher than $9 \%$ of the participants used tobacco products and nearly $28 \%$ of them had the habit eating fast food items. Close to $10 \%$ of the participants were vegetarians and the rest were non-vegetarians.

\section{DISCUSSION}

To best of our knowledge, this is first preliminary report to develop and validate Yoga scale on oral health benefit through modulation of behavior.
The researchers in the present study could develop a PBY scale to measure the perceived benefits of Yoga on the oral health outcomes. Initially there were twelve items in scale, which finally produced six-item scale. Previously described and established steps of psychometric research were followed to develop and validate current scale.

Concept of health promotion and health behavior modification for promotion of health started earlier in nineteenth century. Later on, researchers and social psychologists proposed many models and theories. Health belief model was one of them and evolved in 1960s. Perceived threat to their health and evaluation of health related behavior makes core component of health belief model. In present study, we focused on perceived benefit component for general and oral health.

In recent years, focus has shifted to holistic health concept through yoga and other naturopathic therapies. Many studies have been conducted to show beneficial effect of yoga on health and oral health. Evidence has been generated through systematic reviews and meta analysis of studies related to impact of yoga on hypertension, serum cortisol levels, stress levels associated with periodontal health $[15,16]$.

Similarly, yogic exercises in conjunction with conventional treatment showed striking improvement among MPDS patients [17]. There is no direct evidence of Yoga in management of periodontal diseases, but it can be helpful for patients undergoing periodontal surgery, as yoga reduces stress. [18].

Some researchers have diverse views defining content domain and generating the initial item pool and advocates use of both deductive and inductive methods of generating items. Inductive method involves discussion and consulting experts in their specialized fields whereas deductive method employs extensive review of literature. Morgado et 
al. [19] strongly suggested to have the initial number of items at least twice of number of items in the final instrument. The methodology adopted in the present study is consistent with the recommendation. While reviewing several psychometric instruments, he also pointed out items' ambiguity or being difficult to answer as the major lacunae. However, adequate care was taken in the study to achieve face validity.

The results offered a preliminary proof favoring that the scale is a reliable and valid tool for measuring perceived benefits of yoga in the light of oral health behavioral outcomes. It was demonstrated that the scale is internally consistent. Cronbach's alpha value of 0.92 and composite reliability value of 0.87 are evidence for presence of superior face validity. Our findings are in line with results found by Xiang B and Berhaminia et al. [20,21].

In present study, ratio of Normed Chisquare was found three, which indicates that proposed scale has reasonable fitness to make its construct valid. Results of confirmatory and exploratory factor analysis confirmed our scales usefulness to assess perceived benefits of yoga on oral health. Concurrent validity of present scale was confirmed by scores, which correlated in a significant positive manner with YSES scale.

\section{Limitations of the study}

There were certain limitations in the study. Our study participants sample represent a single, specific region, caution should be taken to generalize these findings. Long-term impact of yoga on health including periodontal health should be considered to prove benefits. So longitudinal studies are to be conducted to further lighten our findings.

\section{CONCLUSION}

Scale developed and validated in the present study may prove useful in further epidemiological and clinical assessment of individuals with oral diseases who practices yoga. Our findings will pave a new path to assess impact of yoga exercises on health and oral health. Longitudinal and rigorously designed trials are needed in future to establish evidence of yoga benefit on health and oral health behavior and validation of new proposed scale.

\section{Acknowledgments}

The authors are grateful to His Holiness Sami Ramdev Ji for his blessings. We are also grateful to Dr Madhan Kumar and Dr Pooja Singh for contributions and critical review of the manuscript and the research fellows for support during the development and writing of this manuscript.

\section{Funding}

Nil

\section{Conflict of interest}

The authors have no proprietary, financial, or other personal interest of any nature or kind in any product, service, and/or company that is presented in this article.

\section{Regulatory Statement}

This study was conducted in accordance with all the provisions of the local human subject's oversight committee guidelines and policies of: Patanjali Bhartiya Ayurvigyan Evam Anusandhan Sansthan. The approval code for this study is: PAC/1002.

\section{REFERENCES}

1. Shamim T. The psychosomatic disorders pertaining to dental practice with revised working type classification. Korean J Pain. 2014;27(1):16-22. doi:10.3344/kjp.2014.27.1.16.

2. Singh K. Effect of yoga on dental care: Pranayama techniques or rhythmic breathing exercises on the oral hygiene and gingival bleeding. Int J Appl Dent Sci. 2017;3(3):91-5.

3. Desikachar K, Bragdon L, Bossart C. The yoga of healing: exploring yoga's holistic model for health and well-being. Int J Yoga Therap. 2005 Jan 1;15(1):17-39.

4. Arora S, Bhattacharjee J. Modulation of immune responses in stress by Yoga. Int J Yoga. 2008 Jul;1(2):45. 
5. Gordon L, McGrowder DA, Pena YT, Cabera E, Lawrence-Wright MB. Effect of yoga exercise therapy on oxidative stress indicators with end-stage renal disease on hemodialysis. Int J Yoga. 2013; 6:31-8.

6. Hollister MC, Anema MG. Health behavior models and oral health: a review. J Dent Hyg. 2004;78(3):6.

7. Bandura A, Freeman W, Lightsey R. Self-efficacy: the exercise of control. New York: W. H. Freeman; 1997.

8. Sohl S, Schnur J, Daly L, Suslov K, Montgomery G. Development of the beliefs about yoga scale. Int J Yoga Therap. 2011 Sep 1;21(1):85-91.

9. Birdee GS, Sohl SJ, Wallston K. Development and psychometric properties of the Yoga Self-Efficacy Scale (YSES). BMC Complement Altern Med. 2015 Dec;16(1):3.

10. Hochbaum G. Health Behavior. Belmont, CA: Wadsworth Publishing; 1970. p.70-4.

11. Monier-Williams M. A Sanskrit English Dictionary 2005 deluxe edition:etymologically and philologically arranged with special reference to Cognate Indo-European languages. Dehli, India: Motilal Banarsi dass; 2005.

12. Hoelter JW. The analysis of covariance structures: goodness-of-fit indices. Sociol Methods Res. 1983 Feb;11(3):325-44

13. Hinkin TR. A brief tutorial on the development of measures for use in survey questionnaires. Organ Res Methods. 1998 Jan;(1):104-21.

14. Glanz K. Theory at a glance: a guide for health promotion practice. U.S. Department of Health and Human Services, Public Health Service, National Institutes of Health, National Cancer Institute, 1997. 48 p.
15. Katuri KK, Dasari AB, Kurapati S, Vinnakota NR, Bollepalli AC, Dhulipalla R. Association of yoga practice and serum cortisol levels in chronic periodontitis patients with stress-related anxiety and depression. J Int Soc Prev Community Dent. 2016 Jan-Feb;6(1):7-14. doi: 10.4103/22310762.175404. PMID: 27011926; PMCID: PMC4784068

16. Park SH, Han KS. Blood pressure response to meditation and yoga: a systematic review and meta-analysis. J Altern Complement Med. 2017 Sep;23(9):685-95. doi: 10.1089/acm.2016.0234. Epub 2017 Apr 6. PMID: 28384004.

17. Khan AA, Srivastava A, Passi D, Devi M, Chandra L, Atri M. Management of myofascial pain dysfunction syndrome with meditation and yoga: Healing through natural therapy. Natl J Maxillofac Surg. 2018 Jul-Dec;9(2):155-9. doi: 10.4103/njms.NJMS 25 17.PMID: 30546229; PMCID: PMC6251288

18. Sudhanshu A, Sharma U, Vadiraja HS, Rana RK, Singhal R. Impact of Yoga on periodontal disease and stress management. Int J Yoga. 2017 SepDec;10(3):121-7. doi: 10.4103/0973-6131.213468. PMID: 29422742; PMCID: PMC5793006

19. Morgado FF, Meireles JF, Neves CM, Amaral AC, Ferreira ME. Scale development: ten main limitations and recommendations to improve future research practices. Psicol Reflex Crit. 2018 Jan;30(1):3.

20. Xiang B, Wong HM, Cao W, Perfecto AP, McGrath CPJ. Development and validation of the oral health behavior questionnaire for adolescents based on the health belief model (OHBQAHBM). BMC Public Health. 2020 May 15;20(1):701. doi: 10.1186/s12889-020-08851-x. PMID: 32414375;PMCID: PMC7227318.

21. Bahramian H, Mohebbi S Z, Khami M R, Shahbazi Sighaldeh S. A Health belief model-based instrument for assessing factors affecting oral health behavior during pregnancy. Iran Red Crescent Med J. 2017; 19(8):e58266. doi: 10.5812/ircmi.5826.

\section{Abhishek Sharma}

(Corresponding address)

Public health dentistry, RUHS College of Dental Sciences (Government Dental College and

Hospital), Jaipur, Rajasthan, India.302016.

Email: drabhi712@gmail.com

Date submitted: 2020 Nov 05

Accept submission: 2021 Jan 12 